\title{
АНАЛІЗ ПОЗИЦІЙ УКРАЇНИ У ВИМІРІ КОНКУРЕНТОСПРОМОЖНІСТЬ - ІННОВАЦІЙНІСТЬ
}

\section{ANALYSIS OF UKRAINE'S POSITION IN THE COMPETITIVENESS - INNOVATIVENESS DIMENSION}

\author{
Чмутова Ірина Миколаївна \\ доктор економічних наук, профресор, \\ Харківський національний економічний університет імені Семена Кузнеця \\ ORCID: https://orcid.org/0000-0001-7932-7652 \\ Гайналій Анастасія Олександрівна \\ студентка, \\ Харківський національний економічний університет імені Семена Кузнеця \\ ORCID: https://orcid.org/0000-0001-8835-0299
}

\author{
Chmutova Iryna, Hainalii Anastasiia \\ Simon Kuznets Kharkiv National University of Economics
}

\begin{abstract}
Стаття присвячена визначенню та аналізу складових конкурентоспроможності України у взаємозв'язку 3 інноваційним розвитком і інноваційними можливостями. Проаналізовано конкурентні позиції України за індексом глобальної конкурентоспроможності (GCI) та за рейтингом конкурентоспроможності країн світу (WCY). Визначено інноваційні здатності України за Глобальним індексом інновацій (GII), показником готовності до майбутнього виробництва (FOP), Індексом мережевої готовності (NRI). Узагальнення характеристик глобальних індексів конкурентоспроможності показало, що на відміну від рейтингу світової конкурентоспроможності (WCY) за версією Міжнародного інституту менеджменту і розвитку, Індекс глобальної конкурентоспроможності дозволяє не лише визначити місце країни, а й одержати бальну оцінку, що використано для позиціонування України у площині конкурентоспроможність-інноваційність. Встановлено, що Україна має вищу за середню оцінку конкурентоспроможності і нижчу за середню оцінку інноваційності, тобто інноваційний розвиток країни через його недостатній рівень не відіграє вирішальної ролі у забезпеченні конкурентоспроможності. При цьому країна має потенціал для покращення позицій.

Ключові слова: конкурентоспроможність, конкурентна позиція, інновації, інноваційний розвиток, індекс глобальної конкурентоспроможності, глобальний індекс інновацій.
\end{abstract}

Статья посвящена определению и анализу составляющих конкурентоспособности Украины во взаимосвязи с инновационным развитием и инновационными возможностями. Проанализированы конкурентные позиции Украины на основе индекса глобальной конкурентоспособности (GCl) и рейтинга конкурентоспособности стран мира (WCY). Определены инновационные способности Украины по Глобальному индексу инноваций (GII), показателю готовности к будущему производству (FOP), Индексу сетевой готовности (NRI). Обобщение характеристик глобальных индексов конкурентоспособности показало, что в отличие от рейтинга мировой конкурентоспособности (WCY) по версии Международного института менеджмента и развития, индекс глобальной конкурентоспособности позволяет не только определить место страны, но и получить балльную оценку, которая использована для позиционирования Украины в плоскости конкурентоспособность-инновационность. Установлено, что Украина имеет оценку конкурентоспособности выше средней и оценку инновационности ниже средней, то есть инновационное развитие страны из-за его недостаточного уровня не играет решающей роли в обеспечении конкурентоспособности. При этом у страны есть потенциал для улучшения позиций.

Ключевые слова: конкурентоспособность, конкурентная позиция, инновации, инновационное развитие, индекс глобальной конкурентоспособности, глобальный индекс инноваций.

The country's competitiveness is a crucial integral characteristic of its development and positioning in the global world. Innovation activity and innovation potential play an important role in shaping the competitive advantages of economically developed countries. Currently, Ukraine's competitive position cannot be considered strong, there is an uneven concentration of innovation in various fields, a widening gap between technological and innovative development of the country, caused by low levels of investment in modernization. The article is devoted to the determining 
and analysis of the components of Ukraine's competitiveness in relation to innovative development and innovative potential. The competitive positions of Ukraine are analyzed on the basis of the Global Competitiveness Index (GCI) and the World Competitiveness Rating (WCY). The innovative abilities of Ukraine were determined according to the Global Innovation Index (GII), the indicator of readiness for future production (FOP), the Network Readiness Index (NRI). A generalization of the characteristics of global competitiveness indices showed that, in contrast to the World Competitiveness Rating (WCY), the global competitiveness index allows not only to get a country's rank, but also to obtain a score, which is used to determine the position of Ukraine in the dimension competitiveness-innovativeness. It has been revealed that Ukraine has a competitiveness score above the average and a innovativeness score below the average, so, the innovative development of the country due to its insufficient level does not play a decisive role in ensuring competitiveness. At the same time, the country has the potential to improve its position. Analysis of the Global Innovation Index, the index of readiness for future production and the network readiness index allowed to determine the general state of innovation in Ukraine, the factors influencing it and the weaknesses of the innovation policy. Based on the analyzed indices, it can be noted that Ukraine occupies the final positions in most rankings, as well as averages in some of them. This indicates an uneven distribution of resources invested in each of the areas of innovation.

Keywords: competitiveness, competitive position, innovation, innovative development, global competitiveness index, global innovation index.

Постановка проблеми. Конкурентоспроможність країни $€$ вирішальною інтегральною характеристикою їі розвитку та позиціонування у глобальному світі. У Національній економічній стратегії на період до 2030 року зазначено, що очікуваними результатами іï реалізації $\epsilon$ фрормування конкурентоспроможних умов для бізнесу та інвестицій і конкурентоспроможність на міжнародному ринку, а економічною візією визначено, що «Україна - найпривабливіша країна економічних можливостей для інвестицій, інновацій, ведення бізнесу; найкраще місце для реалізації творчого потенціалу, втілення ідей і власного розвитку» [1]. Це підкреслює важливість науково-інноваційних і технологічних фракторів як потужної рушійної сили для зростання конкурентоспроможності економіки України.

Інноваційній активності й інноваційному потенціалу належить важлива роль у соормуванні конкурентних переваг економічно розвинених країн. Одним із завдань стратегії «Європа 2020» стало збільшення державних і приватних інвестицій в науково-дослідні роботи до рівня 3\% обсягу ВВП [2], у той час як цей показник для України у 2019 р. склав 0,43\%, а у 2020 р. 0,41\%. Інноваційна діяльність $€$ однією з важливих умов підвищення ефрективності використання ресурсів, що у свою чергу сприяє економічному зростанню. При цьому сукупна фракторна продуктивність напряму залежить від обсягів витрат на науку та інновації відносно ВВП [3, с. 33-34].

Науковцями також визнається ефективність і розвиток інноваційної сорери як вирішальний чинник забезпечення конкурентоспроможності економіки $[4$, с. $15 ; 5$, с. 65; 6, с. 97].

Нині ж конкурентні позиції України не можна вважати потужними, наявна нерівно- мірність концентрації інновацій в різних сорерах, дедалі більший розрив між технологічним та інноваційним розвитком країни, спричинений низьким рівнем інвестування у модернізацію виробництв.

Таким чином, необхідним $є$ визначення та аналіз складових конкурентоспроможності України у взаємозв'язку з інноваційним розвитком і інноваційними можливостями країни.

Аналіз останніх досліджень і публікацій. Визначення конкурентних позицій України у глобальному економічному просторі, а також аналіз її інноваційного розвитку у порівнянні 3 іншими країнами на основі різних міжнародних рейтингів останнім часом становлять науковий інтерес, про що свідчить значна кількість праць дослідників, серед яких: В. М. Головатюк, І. Ю. Підоричева, В. П. Соловйов [4], О. В. Машталер [6], Н. І. Горбаль, О. Ю. Григор'єв, А. Ю. Козачук, Н. Ю. Козачук [7], І. А. Дернова, Т. М. Боровик, Л. В. Кравченко [8], М. В. Ковбатюк, В. В. Шкляр [9], Н. В. Лепетюха, А. С. Липська [10], І. Осьмірко, Н. Солопун [11], М. Є. Шкурат, Ю. І. Миколайчук [12] та ін.

Так, Н. І. Горбаль, О. Ю. Григор'єв, А. Ю. Козачук, Н. Ю. Козачук [7] проаналізували Індекс глобальної конкурентоспроможності України (The Global Competitiveness Index - GCl) та показник, запропонований Міжнародним інститутом менеджменту і розвитку (IMD) «World Competitiveness Yearbook» порівняно з найближчими сусідами і виявили дисбаланси у конкурентній позиції України, які проявляються у достатній кваліфрікації та креативності персоналу на тлі інституційних, макроекономічних і фрінансових проблем, та зробили висновок про необхідність підвищення рівня інноваційного розвитку для забезпечення конкурентоспроможності. 
І. А. Дернова, Т. М. Боровик, Л. В. Кравченко [8] узагальнили оцінки й рейтинги України за складовими Індексу глобальної конкурентоспроможності та рейтинги глобальної конкурентоспроможності за версією IMD у динаміці за 2010-2019 рр. та виявили негативні тенденції за показником здоров'я у результаті скорочення тривалості життя та за показником фрінансової системи за рахунок погіршення показників кредитування приватного сектору. Експерти IMD слабкою стороною називають неефективність уряду.

Робота О. В. Машталера [6] присвячена дослідженню стану інноваційної конкурентоспроможності України за Індексом глобальної конкурентоспроможності, визначенню чинників, що перешкоджають інноваційному розвитку. На основі цього встановлено, що вирішальне значення для посилення інноваційної конкурентоспроможності України належить перегляду ролі фракторів впливу на економічне зростання країни, у першу чергу, відновленню роботи промисловості як фундаменту індустріального розвитку. На необхідності розвитку високотехнологічних галузей промисловості наголошують також М. Є. Шкурат та Ю. І. Миколайчук [12], які здійснили аналіз позиціонування України за глобальними індексами конкурентоспроможності, інноваційного розвитку, а також за показником готовності до майбутнього виробництва і дійшли висновку про головну роль людського капіталу, досліджень, знань, результатів наукових досліджень у забезпеченні інноваційної конкурентоспроможності.

Оцінка позиції України за складниками Глобального інноваційного індексу за 2014-2018 рр., здійснена у роботі Н. В. Лепетюхи та А. С. Липської [10] показала, що Україна за бальними оцінками майже удвічі відстає від країн-лідерів у інноваційній сорері, але у 2016-2017 рр. відбувалося поступове поліпшення ситуації, а у 2018 р. - підвищення ефрективності інновацій. До подібних висновків дійшли також І. Осьмірко, Н. Солопун [11] на основі аналізу Глобального інноваційного індексу за 2020 р., зазначивши про приналежність України до країн з доходом нижче середнього, у яких інноваційна діяльність розвивається швидко. М. В. Ковбатюк, В. В. Шкляр [9] крім Глобального індексу конкурентоспроможності та Глобального інноваційного індексу проаналізували Індекс інноваційного розвитку агентства Bloomberg (Bloomberg Innovation Index), згідно із чим виявили послаблення позиції України у 2019 р. за шістьма із семи складових даного індексу, а також Інноваційний індекс Європейського інноваційного табло (Innovation Union Scoreboard - IUS) та встановили, що Україна належить до групи «повільних інноваторів» - країн, результативність яких нижче $50 \%$ від середнього показника результативності по ЄС.

Виділення невирішених раніше частин загальної проблеми. Віддаючи належне важливості проведених досліджень, слід зазначити, що кожен з глобальних індексів побудований з урахуванням різного складу критеріїв і дає можливість скоріше визначити власну позицію у динаміці і у порівнянні 3 іншими країнами, у той час як встановити рівень конкурентоспроможності та інноваційного розвитку на основі більшості з індексів досить складно. Крім того, для фрормування пріоритетних напрямів підвищення конкурентоспроможності та інноваційної політики країни існує потреба у зіставленні конкурентоспроможності та інноваційності.

Формулювання цілей статті (постановка завдання). Метою статті $€$ аналіз взаємозв'язку конкурентоспроможності та інноваційної спроможності України за допомогою побудови матриці «конкурентоспроможність-інноваційність».

Виклад основного матеріалу дослідження. Для реалізації поставленої мети слід обґрунтувати вибір індексу конкурентоспроможності та інноваційності, які будуть використовуватися для побудови означеної матриці.

У Індекс глобальної конкурентоспроможності (GCl) входять 12 субіндексів, розрахованих на основі 103 показників (вимірюються у діапазоні від 0 до 100 і відображують, якою мірою економіка наближена до межі конкурентоспроможності) для 141 країни. Позиції України за Індексом глобальної конкурентоспроможності у розрізі субіндексів наведено у табл. 1.

Не зважаючи на те, що загальна оцінка конкурентоспроможності України у 2018-2019 рр. залишилася незмінною, було втрачено дві сходинки у рейтингу через низьку макроекономічну стабільність, недостатню розвиненість фрінансової системи та інститутів.

Міжнародним інститутом менеджменту і розвитку на основі 333 критеріїв визначається рейтинг світової конкурентоспроможності (WCY) 64 країн світу у розрізі складових: економічний розвиток, ефективність державного управління, ефективність бізнесу, стан інфрраструктури. Позиції України у цьому рейтингу подані на рис. 1. 
Таблиця 1

Індекс глобальної конкурентоспроможності України

\begin{tabular}{|l|c|c|c|c|}
\hline \multirow{2}{*}{ Складова } & \multicolumn{2}{c|}{$\mathbf{2 0 1 8}$ р. } & \multicolumn{2}{c|}{ 2019 p. } \\
\cline { 2 - 5 } & Оцінка & Ранг & Оцінка & Ранг \\
\hline Інститути & 46 & 110 & 48 & 104 \\
\hline Інфрраструктура & 70 & 57 & 70 & 57 \\
\hline Впровадження ІКТ & 51 & 77 & 52 & 78 \\
\hline Макроекономічна стабільність & 56 & 131 & 58 & 133 \\
\hline Здоров'я & 72 & 94 & 66 & 101 \\
\hline Навички & 69 & 46 & 70 & 44 \\
\hline Товарний ринок & 55 & 73 & 57 & 57 \\
\hline Ринок праці & 59 & 66 & 61 & 59 \\
\hline Фінансова система & 49 & 117 & 42 & 136 \\
\hline Обсяг ринку & 63 & 47 & 63 & 47 \\
\hline Динамічність бізнесу & 55 & 86 & 57 & 85 \\
\hline Інноваційний потенціал & 39 & 58 & 40 & 60 \\
\hline Загальна позиція & 57 & 83 & 57 & 85 \\
\hline
\end{tabular}

Джерело: складено на основі даних [13]

Як видно, за рівнем конкурентоспроможності Україна знаходиться на 54 місці серед 64 країн, тобто у останній десятці. І хоча порівняно з 2017 р. країна покращила позиції, конкурентоспроможність залишається на низькому рівні, у першу чергу через слабкий економічний розвиток. Серед сракторів підвищення конкурентоспроможності України відзначаються: замороження збройного конфрлікту на сході країни, сприяння економічному відновленню та запровадження державного приватного партнерства, особливо для інфраструктурних проектів, запуск повномасштабного ринку енергії та землі, пожвавлення вітчизняного фрондового ринку та системи накопичувального пенсійного забезпечення [14].

Слід зазначити, що цей індекс, на відміну від Індексу глобальної конкурентоспроможності, дозволяє лише визначити місце країни, що $є$ безумовно важливим для міждержавних порівнянь, однак не дає змоги отримати бальну або іншу синтезовану оцінку. Виходячи 3 цього, для позиціонування України у площині конкурентоспроможність-інноваційність будемо використовувати Індекс глобальної конкурентоспроможності.

Рейтинг інноваційних можливостей та результатів інноваційної діяльності країн світової економіки демонструє Глобальний інноваційний індекс (GII). Він вимірює інновації на основі критеріїв, які включають інститути, людський капітал і дослідження, інорраструктуру, кредити, інвестиції, зв'язки, створення, поглинання та поширення знань, а також результати творчої діяльності. До порівняння включено 132 країн за понад 81 показником [15].

Варто взяти до уваги постійне вдосконалення технології оцінки інноваційної діяльності країн за системою Gll, що впливає на зміни сприйняття та порівняння рейтингів. За підсумками даних 2019-2021 рр. рейтинг України подано у табл. 2.

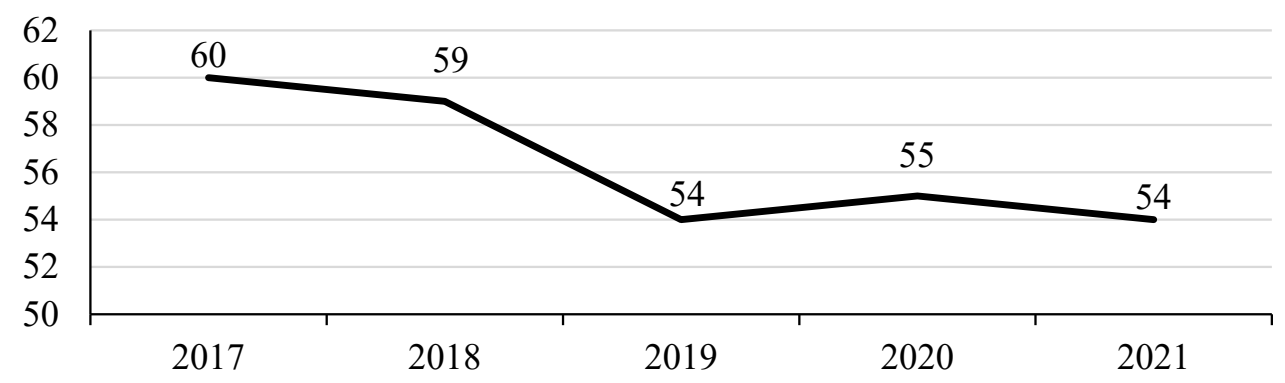

Рис. 1. Позиції України у рейтингу світової конкурентоспроможності (WCY) за версією Міжнародного інституту менеджменту і розвитку 
Таблиця 2

Рейтинг України (2019-2021)

\begin{tabular}{|c|c|c|c|}
\hline Рік & GII & $\begin{array}{c}\text { Iнноваційний } \\
\text { вклад }\end{array}$ & $\begin{array}{c}\text { Інноваційний } \\
\text { результат }\end{array}$ \\
\hline 2021 & 49 & 76 & 37 \\
\hline 2020 & 45 & 71 & 37 \\
\hline 2019 & 47 & 82 & 36 \\
\hline
\end{tabular}

Джерело: складено на основі даних [15]

Аналіз даних звіту за 2021 рік показав, що у поточному році Україна має кращі результати за інноваційними результатами, ніж з інноваційними ресурсами. Також нині вона посідає 76 місце за обсягом інноваційного внеску, що нижче, аніж минулого року, проте на 6 позицій вище, ніж у 2019 році. Також Україна посідає третє місце серед 34-х економік країн 3 середнім та нижчим за середній доходом та 32-е місце серед 39 економік Європи.

За висновками звіту видно, що Україна виробляє більше інноваційного продукту, порівняно 3 рівнем здійснених інвестицій. У 2021 році Україна має найкращі результати в області знань і технологій і найнижчі показники в інфрраструктурі (рис. 2).

Для порівняння, у 2021 році збалансована та висока ефективність за всіма пунктами найбільш чітко проявляється серед лідерів інновацій. Лише 15 економік, включаючи Швейцарію, Швецію, Сполучені Штати, Сінгапур та Францію, тобто $11 \%$ усіх економік, мають високі показники.
Проте, деякі країни, що в загальному рейтингу GII займають нижче місце, посідають лідируючі позиції в окремих ссрерах. Наприклад, Туреччина, яка займає високе місце в рейтингу людського капіталу та досліджень (26-е місце), Таїланд, В'єтнам та Узбекистан з їх відносно високим рейтингом у складності ринку $(27,22$ та 24 місця відповідно) та Монголія, що увійшла в тридцятку за найкращими результатами творчої діяльності (28 місце). Такі результати відображають динамічні зміни інноваційної системи країн, що потенційно можуть призвести до підвищення їх загальної ефективності в майбутньому.

Країнам, які розвиваються, достатньо складно постійно підвищувати свої інноваційні показники, аби відповідати рівню країн з високим рівнем доходів та більш розвинутою економікою. Проте це не перешкоджає Туреччині (41-е місце), Таїланду (43-е місце), В'єтнаму (44-е місце), Російській Федерації (45-е місце), Індії (46-е місце), Україні (49-е місце) і Чорногорії (50-е місце) ввійти в топ-50 рейтингу країн 3 доходами середнього та нижче середнього рівня.

Маючи загальне уявлення про реалізацію інноваційного потенціалу країни, необхідно звернутися до наступного показника, що виокремить та охарактеризує одну з основних складових інновації діяльності - індекс готовності до майбутнього виробництва (Readiness for the Future of Production).

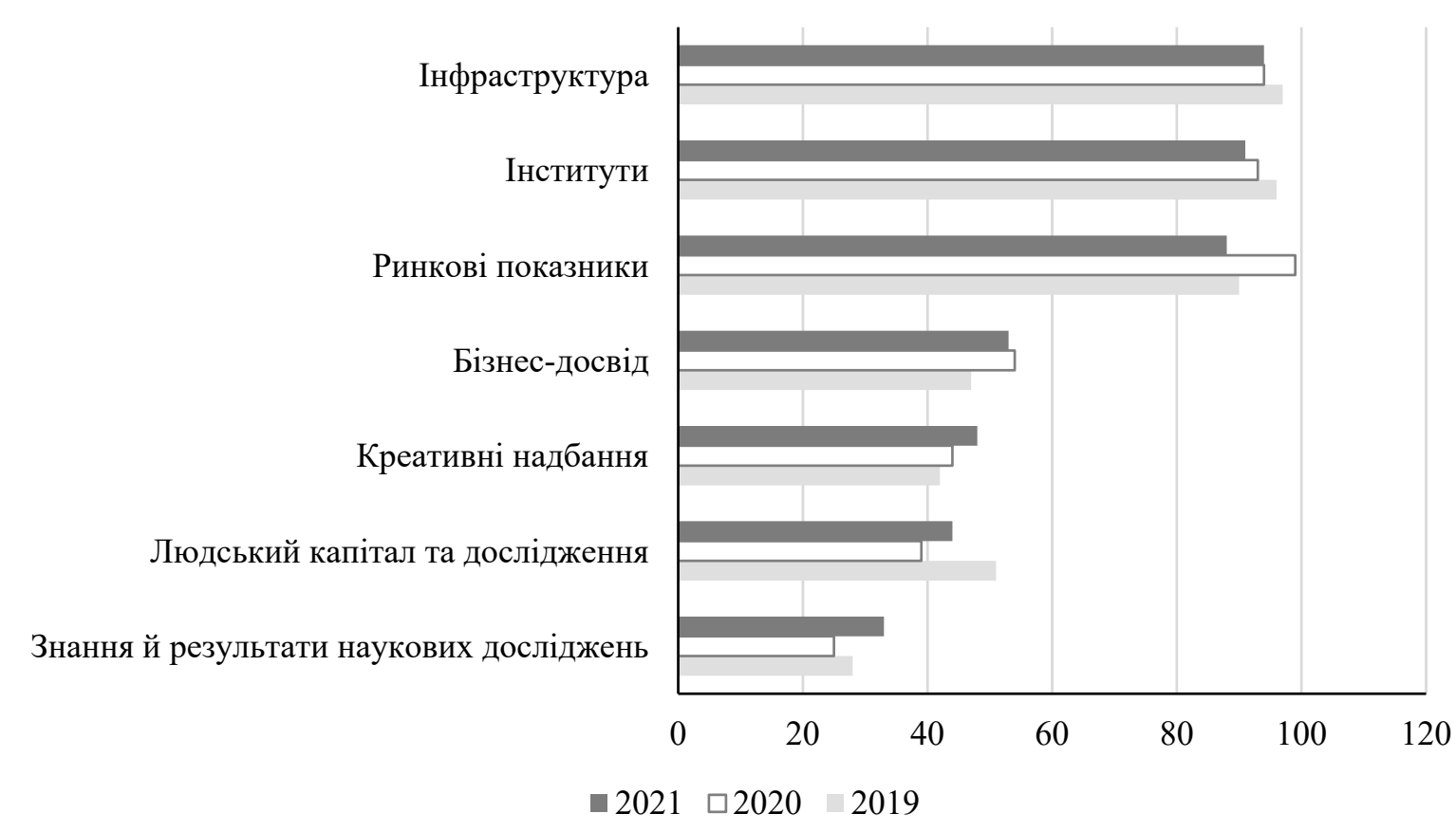

Рис. 2. Рейтинг України за пунктами Глобального індексу інновацій у 2019-2021 pp. Джерело: складено на основі даних [15] 
Як відомо, основним двигуном розвитку інновацій у світовій економіці є виробництво. Можна сказати, що більшість сучасних країн 3 розвинутою та процвітаючою економікою прискорили процес свого зростання саме шляхом ранньої індустріалізації і активного продукування товару, робіт та послуг на ринку. Нині такий спосіб розвитку не втрачає своєї актуальності, проте вимагає дедалі прискіпливішого підходу та аналізу.

Виявлення потенційних можливостей i перспектив, фракторів, що є необхідними для отримання вигоди від технологічних змін і нововведень, а також сприяння структурним перетворенням надалі відіграватимуть все більш вирішальну роль у конкурентоспроможності країн майбутнього.

Індекс готовності до майбутнього виробництва $€$ відносно новим, оскільки був вперше введеним у 2018 році, і при цьому являється новим інструментом діагностики, нововведеною системою порівняльного аналізу даних, що дозволяє викрити ключові важелі та фрактори, необхідні для прийняття управлінських рішень щодо подальшого розвитку та трансформації виробничих систем, та усвідомити рівень готовності та здатності країни отримувати прибуток і вигоди від змінного характеру виробництва, стимулювати співпрацю державного та приватного секторів, а також інформаційно забезпечити суспільство щодо сучасних промислових стратегій та діяльності в галузі виробництва провідних країн світу.

Для здійснення оцінки та висування прогнозів до аналізу включаються основні стимули та фрактори, що дозволяють країнам впроваджувати нові технології, підвищувати свою продуктивність і трансорормувати виробничі системи. Так, система розрахунку визначає ключові важелі, необхідні для ефективної трансорормації виробничих систем у сорері технологій, що швидко розвиваються.

Індекс визначає готовність до майбутнього виробництва за двома різними компонентами: структурою (складність, масштаб) та рушіями виробництва (технології та інновації, людський капітал, глобальні тенденції та інвестиції, інституційна інсрраструктура, стійкі ресурси, середовище попиту) [16].

Рушії виробництва $є$ ключовими фракторами, які дають змогу країні використовувати нові технології та можливості майбутнього виробництва. Серед них визначено основні шість: технології та інновації, людський капітал, глобальна торгівля та інвестиції, інституційна структура, стійкі ресурси та середовище попиту. Кожен з них має відповідні категорії, підкатегорії та індикатори. Країни, які добре позиціонуються за всіма пунктами, вважаються більш «готовими», оскільки поєднання фракторів дозволить впровадити та поширити технології майбутнього з метою прискорення транссрормації виробничих систем.

Серед наведених показників важливим буде виокремити саме оцінку технології та інновації, що виражає, на скільки розвиненою, безпечною та системною $€$ інфрраструктура інфрормаційних та комунікаційних технологій (IКT) країни, чи достатній її розвиток для впровадження нових технологій. Також цей фрактор вимірює здатність країни стимулювати розробку інновації та комерціалізувати ті, які мають потенційне застосування у звичайній діяльності.

Технології та інновації $€$ ключовим фрактором майбутнього виробництва, оскільки впровадження та поширення нових технологій $€$ основою Четвертої промислової революції. Для цього країнам потрібна розвинута та безпечна технологічна база, складовими якої є: наявність IKT; використання IKT; цифрова безпека і коноріденційність даних; промислова діяльність; інтенсивність дослідження; доступне фрінансування [16].

За рушієм «Технології та інновації» у звіті 2018 року [16] по Україні наведені такі дані (табл. 3).

Наведені дані показують, що в Україні досить розповсюджений стільниковий зв'язок, відповідно до чого вона посідає 32 позицію у рейтингу зі 100 країн, достатньою розвиненістю характеризується багатостороння співпраця (47-е місце) країни щодо наукової та комунікаційно-технологічної діяльності; витрати на НДДКР (50-е місце) свідчать про помірні інвестиції у розвиток науки, як зі сторони держави, так і зі сторони її населення, що впроваджує управлінські рішення та політику, спрямовані на розвиток IKT (це також підтверджується 51-м місцем рейтингу за кількістю наукових видань).

Виходячи 3 результатів аналізу також спостерігається недостатній розвиток кластеру (87-е місце), причиною чому є мала частка формування підприємствами, установами та організаціями бізнес-моделей з підтримкою IKT (92-е місце), слабке стимулювання до передачі новостворених технологій (95-е місце), спричинене стереотипним мисленням про «крадіжку» оригінальних ідей та небажанням розділяти 3 конкурентами прибутків від використання інновації. Покриття мобільної мережі LTE розміщує 
Драйвер «Технології та інновації» у складі Індексу готовності

Таблиця 3 до майбутнього виробництва України у 2018 р.

\begin{tabular}{|c|c|c|c|c|}
\hline & Складова фрактору & $\begin{array}{c}\text { Спосіб } \\
\text { оцінювання }\end{array}$ & Рейтинг/100 & Значення \\
\hline 2.1 & Підписка на мобільний стільниковий зв'язок & на 100 осіб & 32 & 132,6 \\
\hline 2.2 & Покриття мобільної мережі LTE & \% населення & 98 & 1,4 \\
\hline 2.3 & Користувачі Інтернету & \% осіб & 71 & 52,5 \\
\hline 2.4 & ПІІ та передача технологій & $1-7$ & 95 & 3,5 \\
\hline 2.5 & Поглинання технології на рівні фрірми & $1-7$ & 71 & 4,3 \\
\hline 2.6 & Бізнес-моделі з підтримкою IKT & $1-7$ & 92 & 4 \\
\hline 2.7 & Зобов'язання щодо кібербезпеки & $0-1$ & 59 & 0,5 \\
\hline \multicolumn{2}{|r|}{ Здатність до інновацій } & $0-10$ & 68 & 2 \\
\hline 2.8 & Стан розвитку кластера & $1-7$ & 87 & 3,1 \\
\hline 2.9 & Інвестиції компаній у новітні технології & $1-7$ & 60 & 3,5 \\
\hline 2.10 & Державні закупівлі передових технологій & $1-7$ & 72 & 3 \\
\hline 2.11 & Компанії, які приймають проривні ідеї & $1-7$ & 72 & 3,2 \\
\hline 2.12 & Багатостороння співпраця & $1-7$ & 47 & 3,7 \\
\hline 2.13 & Витрати на НДДКР & $\%$ ВВП & 50 & 0,7 \\
\hline 2.14 & Науково-технічні видання & $\begin{array}{c}\text { к-сть на } \\
\text { млрд. дол. США }\end{array}$ & 51 & 12,2 \\
\hline 2.15 & Заявки на патент & к-сть на млн. осіб & 58 & 1,08 \\
\hline 2.16 & Обсяг угоди з венчурним капіталом & млн. дол. США & 56 & 1643,5 \\
\hline 2.17 & $\begin{array}{l}\text { Обсяг венчурних угод за розміром } \\
\text { економіки }\end{array}$ & дол. США/ВВП & 53 & 15,5 \\
\hline
\end{tabular}

Джерело: складено на основі даних [16]

Україну на прикінцевих позиціях (98-е місце). Такий низький показник є яскравим втіленням слабкості ІКТ-системи на рівні країни, оскільки більшість населених пунктів не мають подібного покриття, а отже користуються застарілими технологіями і не мають значного потенціалу до створення нових.

Таким чином неможливо говорити про готовність України до Четвертої промислової революції, а також про високий розвиток інноваційної діяльності. На даний момент країна не здатна реалізувати свій технологічний потенціал і використати вже наявні в ній ресурси, людський капітал та інвестиції.

Архетип економіки України [16] характеризує її у як країну в стані зародження розвитку, з базовою структурою виробництва і найменш готовою до майбутнього.

Як видно зі структури фрактору «Технології та інновації», доволі значимим показником в ній $€$ інсрормаційно-комунікаційні технології, що у свою чергу відображають здатність країни забезпечити створення, освоєння, перетворювання, застосування і поширення значних масивів інфрормації їі населенням.

Звичайно, що для прийняття правильних стратегій державам, підприємствам, ана- літикам та окремим громадянам необхідні конкретні показники, що дозволяють відслідковувати основні тенденції світу. Проте одним 3 ключових питань $€$ те, як саме ці зацікавлені сторони будуть співпрацювати (i/або конкурувати) та повноцінно використовувати можливості, надані технологічними інноваціями, з метою вирішення поточних і майбутніх проблем.

У вирішенні цього питання доречним $€$ використання фрактів та показників, які ввійшли до звіту щодо Індексу мережевої готовності (Network Readiness Index). Цей звіт, на базі дослідження 134 економік світу, оцінює, як країни використовують інформаційні технології, щоб бути готовими до майбутнього [17]. Перше видання «нового ІМГ» вийшло у 2020 році. У ньому відображено збалансованість показників технологічного і людського виміру мережевої готовності. Звіт підкреслює важливість вимірювання довіри, безпеки, коноріденційності та здатності використовувати технологічні зміни для вирішення поточних та майбутніх проблем, глобальних викликів, таких як зміна клімату, та прискорення реалізації Цілей сталого розвитку. 
Структура індексу має наступний вигляд:

1. Технологія. Технологія лежить в основі мережевої економіки. Цей показник відображає оцінку рівня технологій, який $€$ обов'язковою умовою для участі країни в глобальній економіці.

2. Люди. Наявність і рівень технологій у країні сприймаються в тій мірі, у якій ії населення та структури мають доступ, ресурси та навички для продуктивного використання. Таким чином, цей рівень стосується застосування IKT людьми на трьох рівнях аналізу: особи, підприємства та держава.

3. Управління: наскільки безпечно почуваються люди та форми в контексті мережевої економіки, якою мірою держава сприяє участі в мережевій економіці за допомогою регулювання.

4. Вплив. Зрештою, готовність у мережевій економіці $\epsilon$ засобом покращення зростання та добробуту суспільства та економіки. Тому цей рівень спрямований на оцінку економічного, соціального та людського впливу на участь в мережевій економіці.

Результати звіту ІМГ 2020 тісно пов'язані 3 рівнем доходу. Тому у звіті прослідковується поділ на країни з високим, вище середнього, нижче середнього та низьким рівнями доходів. Україна $€$ однією 3 трійки лідерів країн 3 рівнем доходів нижче середнього і посідає 64 місце в загальному рейтингу.

Найсильнішою якісною характеристикою України є управління (58-е місце), де достатньо високим $€$ рівень довіри (49-е місце), що 3 боку навколишнього середовища та поведінки людей, нівелюється значно слабшим регулюванням (83-е місце) та інклюзією (72-е місце).

Також, за даними табл. 4 видно, що Україна доволі добре працює з розвитком та впровадженням технології (62-е місце), що є очікуваним результатом, оскільки країна має перевагу в розробці програмного забезпечення для роботи 3 цифровим контентом (46-е місце).

Важливо зазначити, що Україна знаходиться на середніх позиціях за інвестиціями у технології і потрапила до третього квартилю позиції «Люди» (65-е місце), де вона, як правило, має кращі показники, що стосуються цифрових навичок, а не використання IKT.

Найслабшим показником України $€$ вплив (79-е місце).

Низький рівень готовності виражається у слабкому стимулюванні підприємств та організацій до дотримання Цілей сталого розвитку (91-е місце). Також органам влади та управління варто звернути увагу на питання здоров'я, благополуччя та стійкості, аби підвищити якість життя населення (77-е місце).
Таблиця 4

Індекс мережевої готовності України у 2020 р. та його складові

\begin{tabular}{|l|c|c|}
\hline \multicolumn{1}{|c|}{ Показник } & Рейтинг/134 & 3начення \\
\hline $\begin{array}{c}\text { Мережевий } \\
\text { індекс готовності }\end{array}$ & 64 & 49,43 \\
\hline \multicolumn{1}{|c|}{ Технологія } & 62 & 41,51 \\
\hline 1. Доступ & 79 & 54,12 \\
\hline 2. Зміст & 46 & 39,9 \\
\hline $\begin{array}{l}\text { 3. Технології } \\
\text { майбутнього }\end{array}$ & 53 & 30,5 \\
\hline \multicolumn{1}{|c|}{ Люди } & 65 & 48,87 \\
\hline 1. Фізичні особи & 63 & 56,22 \\
\hline 2. Підприємства & 52 & 48,53 \\
\hline 3. Держави & 71 & 41,85 \\
\hline \multicolumn{1}{|c|}{ Управління } & 58 & 58,19 \\
\hline 1. Довіра & 49 & 50,66 \\
\hline 2. Регулювання & 83 & 61,48 \\
\hline 3. Включення & 72 & 62,42 \\
\hline \multicolumn{1}{|c|}{ Вплив } & 79 & 49,16 \\
\hline 1. Економіка & 62 & 26,17 \\
\hline 2. Якість життя & 77 & 62,86 \\
\hline 3. Внесок у ЦСР & 91 & 58,46 \\
\hline
\end{tabular}

Джерело: складено на основі даних [18]

Проаналізувавши індекси розвитку інновацій, можна констатувати, що найбільш придатним $з$ позиції зіставлення з рівнем конкурентоспроможності $€$ складові Глобального інноваційного індексу, оскільки вони характеризують не лише місце серед інших країн, але й мають бальну оцінку. Важливим також $\epsilon$ забезпечення порівнянності даних з огляду на те, що Індекс глобальної конкурентоспроможності розраховано лише до 2019 р., у той час як Індекс готовності до майбутнього виробництва наявний лише для 2018 р., а Індекс мережевої готовності - для 2020 р.

Зіставлення конкурентоспроможності та інноваційного розвитку України подано на рис. 3. При цьому у якості оцінки інноваційності використано середній бал за складовими Глобального інноваційного індексу «Інститути», «Людський капітал та дослідження», «Інфрраструктура», «Ринкові показники», «Бізнес-досвід», «Знання й результати наукових досліджень», «Креативні надбання».

Як видно, Україна має вищу за середню оцінку конкурентоспроможності і нижчу за середню оцінку інноваційності, отже інноваційний розвиток країни через його недостатній рівень не відіграє вирішальної ролі у забезпеченні конкурентоспроможності. Варто зауважити, що Україна має достатній потенціал 


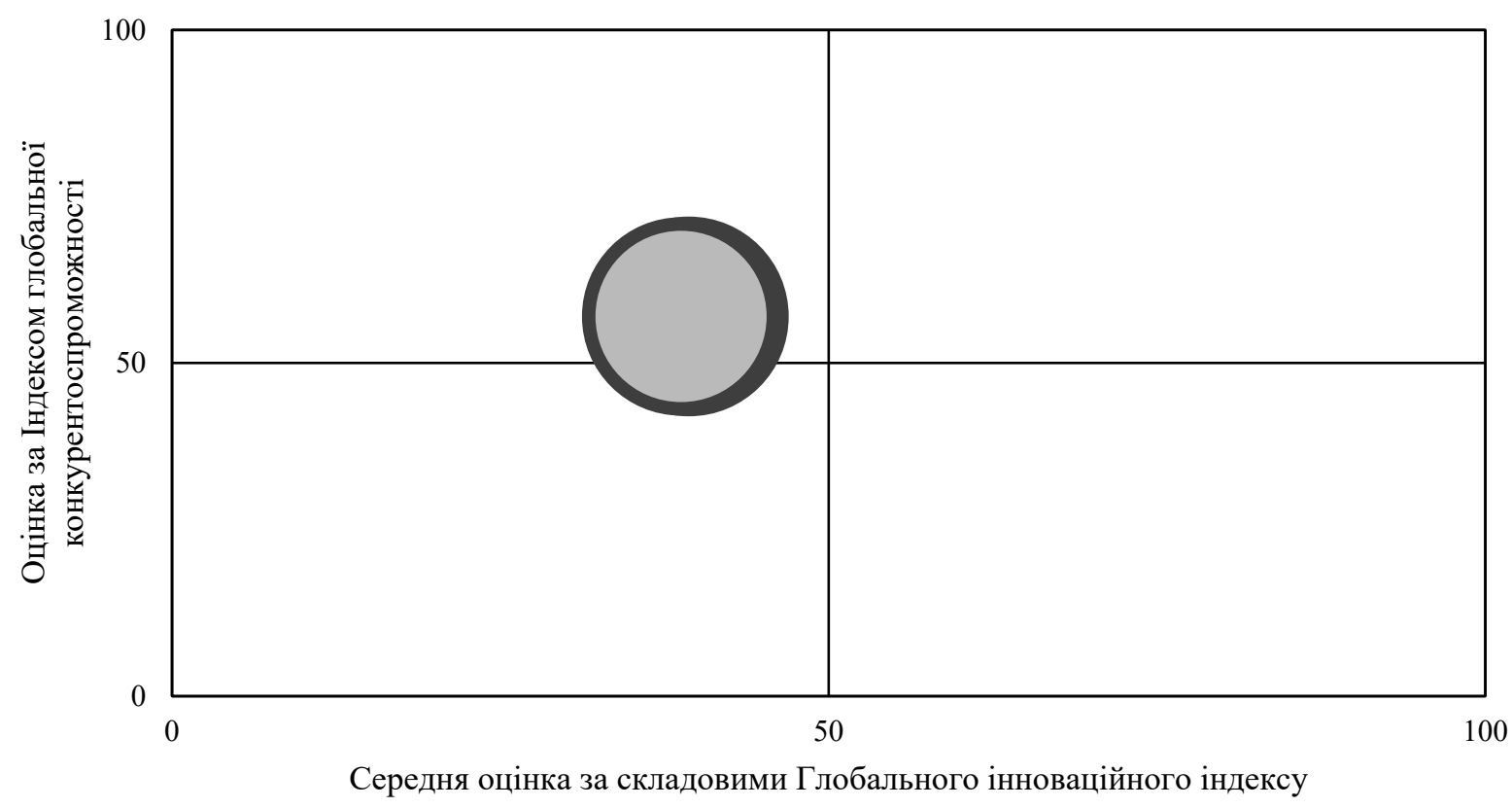

$2018 \bullet 2019$

Рис. 3. Позиція України у матриці «конкурентоспроможність-інноваційність» у 2018-2019 рр. Джерело: складено авторами

для розвитку. Вона може сприяти створенню інновацій за допомогою різних фракторів: географічні кластери, державні закупівлі передових технологій і співпраця між науковими, державними та промисловими інститутами. Також, для підтримки перспективних змін, необхідними $є$ сильна фрінансова система та розвинене інституційне середовище.

Висновки. Узагальнення характеристик глобальних індексів конкурентоспроможності показало, що на відміну від рейтингу світової конкурентоспроможності (WCY) за версією Міжнародного інституту менеджменту і розвитку, Індекс глобальної конкурентоспроможності дозволяє не лише визначити місце країни, а й одержати бальну оцінку, що використано для позиціонування України у площині конкурентоспроможність-інноваційність.

Глобальний індекс інновацій дозволяє визначити поточний стан та результати реалізації інноваційного потенціалу та прийнятих щодо нього управлінських рішень на рівні країни і $€$ одним з інструментів фрормування державної політики щодо підвищення інноваційності національної економіки.

Індекс готовності до майбутнього виробництва дозволяє викрити ключові важелі та фрактори, необхідні для прийняття управлінських рішень щодо подальшого розвитку та трансформації виробничих систем, та усвідомити рівень готовності та здатності країни отриму- вати прибуток і вигоди від змінного характеру виробництва.

Індекс мережевої готовності акцентує увагу на вимірювання довіри, безпеки, конфріденційності та здатності використовувати технологічні зміни для вирішення поточних та майбутніх проблем, глобальних викликів, таких як зміна клімату, та прискорення реалізації Цілей сталого розвитку. Його складові (технології, люди, управління, вплив) дозволяють детально розглянути кожний з фракторів впливу на інноваційну діяльність країни.

Аналіз таких показників, як Глобальний індекс інновацій, індекс готовності до майбутнього виробництва та індекс мережевої готовності дозволив визначити загальний стан інноваційної діяльності України, фрактори впливу на нього та слабкі сторони розвитку інноваційної політики держави. На основі проаналізованих індексів можна зазначити, що Україна посідає прикінцеві позиції у більшості рейтингів, а також середні показники у деяких з них. Це свідчить про нерівномірність розподілу ресурсів, які інвестуються у кожну зі ссрер впровадження інновацій.

Напрями подальших досліджень можуть бути пов'язані 3 кількісним визначенням зв'язку між показниками конкурентоспроможності й інноваційності на рівні країн з метою встановлення найбільш впливових складових інноваційного розвитку для забезпечення сильних конкурентних позицій. 


\section{СПИСОК ВИКОРИСТАНИХ ДЖЕРЕЛ:}

1. Національна економічна стратегія на період до 2030 року, затверджена постановою Кабінету Міністрів України від 3 березня 2021 р. № 179. URL: https://www.kmu.gov.ua/npas/pro-zatverdzhennya-nacionalnoyi-eko-a179

2. Europe 2020. A European strategy for smart, sustainable and inclusive growth. Brussels, 2010. 32 p.

3. Писаренко Т.В., Куранда Т.К., Кваша Т.К. та ін. Стан науково-інноваційної діяльності в Україні у 2020 році : науково-аналітична записка. Київ : УкрIHTEI, 2021. 39 с.

4. Головатюк В.М., Підоричева І.Ю., Соловйов В.П. Стратегічні ризики наукоємного розвитку національної економіки. Наука та наукознавство. 2018. № 3(101). С. 3-24.

5. Ольвінська Ю.О., Самотоєнкова О.В., Вітковська К.В. Сучасний стан та тенденції розвитку інноваційної діяльності в Україні. Економіка та держава. 2021. № 4. C. 64-71. DOI: https://doi.org/10.32702/2306-6806.2021.4.64

6. Машталер О.В. Стан інновацій в Україні та їх вплив на позиції конкурентоспроможності в глобальній економіці. Інвестиції: практика та досвід. 2020. № 24. С. 96-106. DOI: https://doi.org/10.32702/2306_6814. 2020.24.96

7. Горбаль Н.І., Григор'єв О.Ю., Козачук А.Ю., Козачук Н.Ю. Україна в рейтингах глобальної конкурентоспроможності. Менеджмент та підприємництво в Україні: етапи становлення і проблеми розвитку. 2019. Вип. 1. № 1. C. 84-91. DOI: https://doi.org/10.23939/smeu2019.01.084

8. Дернова І.А., Боровик Т.М., Кравченко Л.В. Глобальний вимір конкурентоспроможності України. Інфрраструктура ринку. 2020. Вип. 42. С. 29-34.

9. Ковбатюк М.В., Шкляр В.В. Порівняльна оцінка інноваційного розвитку країн світу. Збірник наукових праць ДУІТ. Серія «Економіка і управління». 2020. Вип. 47. С. 71-83. DOI: https://doi.org/10.32703/2664-29642020-47-71-83

10. Лепетюха Н.В., Липська А.С. Оцінювання інноваційної активності промислових підприємств регіонів України. Економіка і суспільство. 2018. Вип. 18. С. 150-158. DOI: https://doi.org/10.32782/2524-0072/2018-18-21

11. Осьмірко І., Солопун Н. Аналіз сучасного стану інноваційної ссрери в Україні. Проблеми і перспективи розвитку підприємництва. 2021. № 26. C. 98-108. DOI: https://doi.org/10.30977/PPB.2226-8820.2021.26.98

12. Шкурат М.Є., Миколайчук Ю.І. Україна у глобальному інноваційному просторі. Економіка і організація управління. 2020. № 4(40). C. 9-17. DOI: https://doi.org/10.31558/2307-2318.2020.4.1

13. World Economic Forum. Reports. URL: https://www.weforum.org/reports

14. IMD World Competitiveness Rankings 2021 Ukraine. URL: https://worldcompetitiveness.imd.org/ countryprofile/UA/wcy

15. Global Innovation Index (GII). World Intellectual Property Organization URL: https://www.wipo.int/global_ innovation_index/en/

16. The Readiness for the Future of Production Report 2018. World Economic Forum. URL: www3.weforum.org/ docs/FOP_Readiness_Report_2018.pdf

17. Network Readiness Index. Portulans Institute. 2020. URL: https://networkreadinessindex.org/

18. Network Readiness Index, Ukraine. Portulans Institute. 2018. URL: https://networkreadinessindex.org/ country/ukraine/

\section{REFERENCES:}

1. Nacionalna ekonomichna strategiya na period do 2030 roku [National economic strategy to 2030], zatverdzhena postanovoyu Kabinetu Ministriv Ukrayiny vid 3 bereznya 2021 r. № 179. Retrieved from: https://www.kmu.gov.ua/npas/pro-zatverdzhennya-nacionalnoyi-eko-a179

2. Europe 2020 (2010) A European strategy for smart, sustainable and inclusive growth. Brussels, $32 \mathrm{p}$.

3. Pysarenko T.V., Kuranda T.K., Kvasha T.K. ta in. (2021) Stan naukovo-innovacijnoyi diyalnosti v Ukrayini u 2020 roci: naukovo-analitychna zapyska [The state of scientific and innovative activity in Ukraine in 2020: scientific and analytical note]. Kyiv: UkrINTEI, $39 \mathrm{p}$.

4. Golovatyuk V.M., Pidorycheva I.Yu., Solovjov V.P. (2018) Strategichni ryzyky naukoyemnogo rozvytku nacionalnoyi ekonomiky [Strategic risks of science-intensive development of the national economy]. Nauka ta naukoznavstvo, 3(101), 3-24.

5. Olvinska Yu.O., Samotoyenkova O.V., Vitkovska K.V. (2021) Suchasnyj stan ta tendenciyi rozvytku innovacijnoyi diyalnosti v Ukrayini [Current state and trends in innovation in Ukraine]. Ekonomika ta derzhava, 4, 64-71. DOI: https://doi.org/10.32702/2306-6806.2021.4.64

6. Mashtaler O.V. (2020) Stan innovacij v Ukrayini ta yix vplyv na pozyciyi konkurentospromozhnosti v globalnij ekonomici [The state of innovation in Ukraine and their impact on the position of competitiveness in the global economy]. Investyciyi: praktyka ta dosvid, 24, 96-106. DOI: https://doi.org/10.32702/2306_6814.2020.24.96 
7. Gorbal N.I., Grygor'yev O.Yu., Kozachuk A.Yu., Kozachuk N.Yu. (2019) Ukrayina v rejtyngax globalnoyi konkurentospromozhnosti [Ukraine in the rankings of global competitiveness]. Menedzhment ta pidpryyemnycztvo v Ukrayini: etapy stanovlennya i problemy rozvytku, 1(1), 84-91. DOI: https://doi.org/10.23939/smeu2019.01.084

8. Dernova I.A., Borovyk T.M., Kravchenko L.V. (2020) Globalnyj vymir konkurentospromozhnosti Ukrayiny [Global dimension of Ukraine's competitiveness]. Infrastruktura rynku, 42, 29-34.

9. Kovbatyuk M.V., Shklyar V.V. (2020) Porivnyalna ocinka innovacijnogo rozvytku krayin svitu [Comparative assessment of innovative development of the world]. Zbirnyk naukovyh pracz DUIT. Seriya «Ekonomika i upravlinnya», 47, 71-83. DOI: https://doi.org/10.32703/2664-2964-2020-47-71-83

10. Lepetyuxa N.V., Lypska A.S. (2018) Ocinyuvannya innovacijnoyi aktyvnosti promyslovyx pidpryyemstv regioniv Ukrayiny [Evaluation of innovation activity of industrial enterprises in the regions of Ukraine]. Ekonomika $i$ suspilstvo, 18, 150-158. DOI: https://doi.org/10.32782/2524-0072/2018-18-21

11. Osmirko I., Solopun N. (2021) Analiz suchasnogo stanu innovacijnoyi sfery v Ukrayini [Analysis of the current state of the innovation sphere in Ukraine]. Problemy i perspektyvy rozvytku pidpryyemnycztva, 26, 98-108. DOI: https://doi.org/10.30977/PPB.2226-8820.2021.26.98

12. Shkurat M.Ye., Mykolajchuk Yu.I. (2020). Ukrayina u globalnomu innovacijnomu prostori [Ukraine in the global innovation space]. Ekonomika i organizaciya upravlinnya, 4(40), 9-17. DOI: https://doi.org/10.31558/23072318.2020.4.1

13. World Economic Forum. Reports. Retrieved from: https://www.weforum.org/reports

14. IMD World Competitiveness Rankings 2021 Ukraine. Retrieved from: https://worldcompetitiveness.imd.org/ countryprofile/UA/wcy

15. Global Innovation Index (GII). World Intellectual Property Organization Retrieved from: https://www.wipo.int/ global_innovation_index/en/

16. The Readiness for the Future of Production Report 2018. World Economic Forum. Retrieved from: www3.weforum.org/docs/FOP_Readiness_Report_2018.pdf

17. Network Readiness Index. Portulans Institute. 2020. Retrieved from: https://networkreadinessindex.org/

18.Network Readiness Index, Ukraine. Portulans Institute. 2018. Retrieved from: https://networkreadinessindex.org/ country/ukraine/ 